\title{
The Impact of Economic Growth and Distribution of Zakat Funds on Poverty (Survey in the Third District of West Java Province Period 2011-2016)
}

\section{Fitri Nurjanah, Kusnendi, and Juliana}

Islamic Economics and Finance Department, University of Indonesia, Jl. Dr. Setiabudhi No. 229 Bandung City

\section{Abstract}

Indonesia is a developing country that measures its development success in terms of its economic growth. West Java Province is one of the provinces that is the center of development because it has a large population and has good economic growth and increases every year seen from the GRDP at constant prices. In addition, there are many strategic economic sectors located in West Java Province. So that the potential and

Corresponding Author:

Fitri Nurjanah

fitrinurjanah13@student.upi.edu

Received: 10 February 2019

Accepted: 14 March 2019

Published: 28 March 2019

Publishing services provided by

Knowledge E

(c) Fitri Nurjanah et al. This

article is distributed under the

terms of the Creative Commons

Attribution License, which

permits unrestricted use and

redistribution provided that the

original author and source are

credited.

Selection and Peer-review under the responsibility of the ICIEBP Conference Committee.

\section{G OPEN ACCESS} collection of zakat funds is the highest compared to other provinces. This is expected to alleviate poverty problems in West Java Province, especially in Region III of West Java Province. This study uses secondary data from 2011-2016. The analysis technique used is panel data regression. Based on the results of the analysis found that economic growth and the distribution of zakat funds simultaneously have a significant effect on the number of poor people. Partial economic growth has a negative and significant effect on the number of poor people. While the partial distribution of zakat does not have a negative and insignificant effect on the number of poor people. Variables that have the most dominant influence on the number of poor people are economic growth variables.

Keywords: Economic Development, Poverty, Economic Growth, Distribution, Zakat Distribution Funds

\section{Introduction}

In the context of developing countries, the problem of poverty still revolves around two main aspects. The level of poverty itself and large inequality in income distribution or economic inequality (Athoillah, 2014). It is known that poverty levels in Indonesia are fluctuating and tend to decline annualy. This can be seen in Figure 1. However, the changes are slow and still leave a large number of poor people. Although the determination of the poverty line is very low, in the period of March 2018 it is Rp. 401 220 (or around USD \$29) (BPS, 2018). 


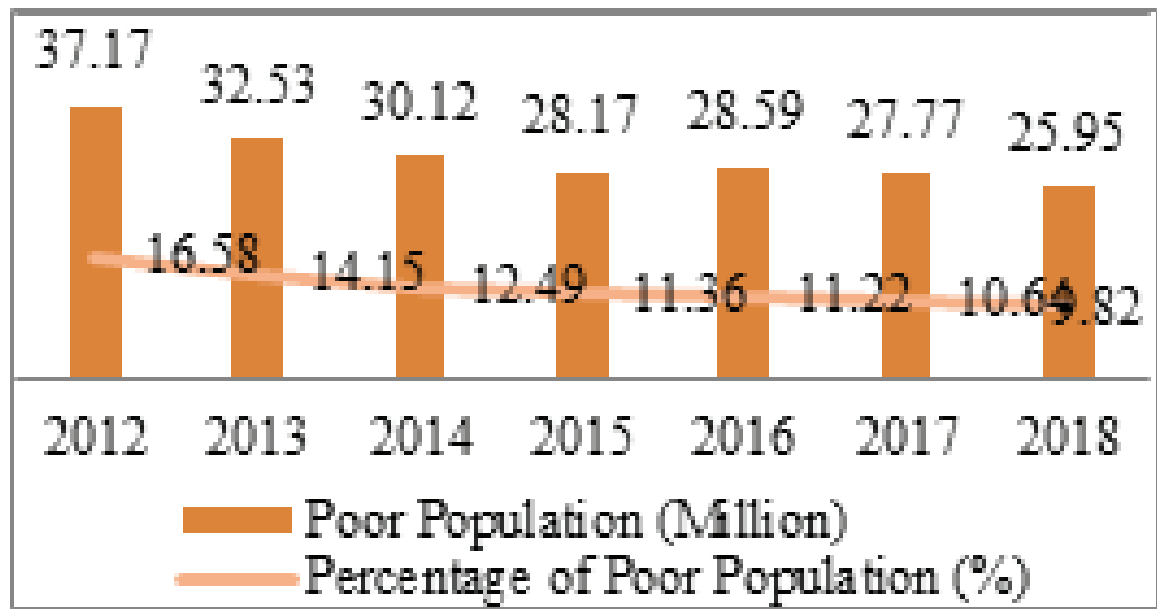

Figure 1: Poverty Statistics and IndonesiaSource: World Bank and Badan Pusat Statistik (BPS) 2007-2017 (data processed).

In the period March 2018, BPS (2018) stated that the West Java Province was the third largest number of poor after Central Java Province and East Java. There were 3,615 million poor people with a percentage of the poor population of $7.45 \%$ and per capita expenditure per month below the national poverty line of Rp. 367,755. However, this number has decreased significantly according to the BPS of West Java Province (2018).

West Java Province divides several regions base on coordination of regional government and development. One of them is The Third District of West Java Province which covers the Cirebon Region and its surroundings. It had a collection of CIAYUMAJAKUNING regions (Cirebon, Indramayu, Majalengka and Kuningan) with regional categories including beaches, lowlands, hills and mountains (BKPP JABAR, 2018). Then will be the focus of the discussion in this study.

BPS West Java Province (2018) states that The Third District of West Java Province was contributed $20 \%$ of the number of poor people in West Java or as much as 852.21 thousand people in 2016. Then, according to the survey results of the West Java Provincial Government published by dawabarat.com (2018) lists the poorest districts / cities in West Java Province which states that The Third District of West Java Province is the poorest and disadvantaged region compared to other coordinating regions. Although the determination of the poverty line is above the poverty line of West Java Province according to BPS (2018).

In connection with the problem of poverty, Shaikh (2016) said that the world has enough resources but did not distributed equally. These indicates that the condition of the structure or order of life is not profitable because it does not make welfare and perpetuate poverty in society (BPS, 2017). Thus an appropriate strategy is needed in the effort to reduce structural poverty. 
Poverty alleviation strategies in economic development still face a classic problem between growth and income distribution (Almizan, 2016) One of the economic development theories uses economic growth as one of the indicators of successful development to reducing poverty (Indonesia-Investments, 2018)

In this case, which is one of the important indicators to determine the role and economic potential in a region in a certain period, namely the Gross Regional Domestic Product (GRDP) (Syahrul, 2009). Based on the publication of BPS data, The Third District of West Java Province in 2016 had an average GRDP at constant prices reaching Rp. 26292.2 billion and has a contribution of 13\% to the economy in West Java Province (BPS, 2017) It can be concluded that an increase in economic conditions can be seen in Figure 2.

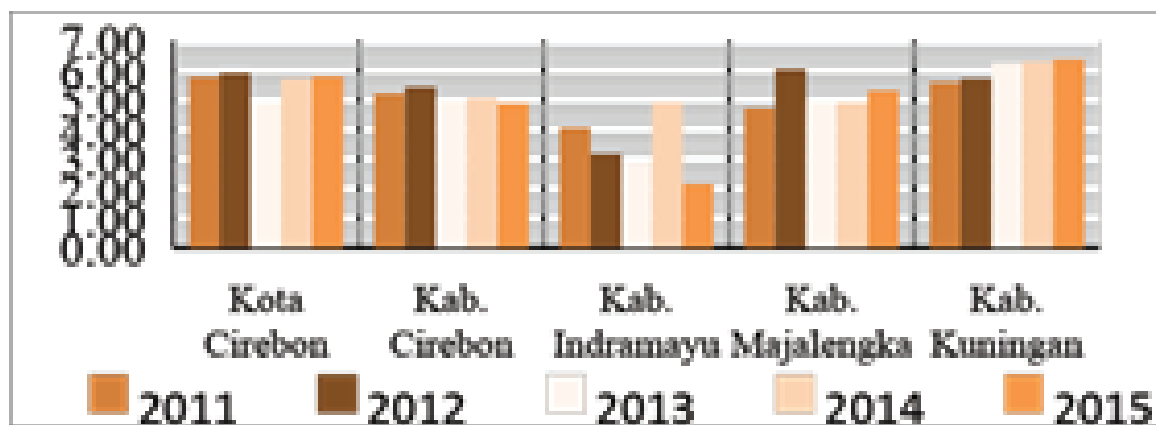

Figure 2: GRDP Growth Rate Based on 2010 Constant Prices According to Regency / City in West Java (Percent)Source: BPS (2017) 2011-2015 period.

In determined poverty phenomenon. Islam recognizes that in life there will definitely be differences in economic income among economic actors, because this is sunnatullah (Indonesia-Investments, 2018). However, this phenomenon is inappropriate just accepted and mourned as qadarullah. Even though Allah SWT has given various forms of choice in an effort to solve poverty problems in the Qur'an and Sunnah (An-Nabhani, 2010). According to Qaradhawi (2005) there are several ways to reduce poverty, there are by working, guaranteeing family guarantees and through zakat.

Indonesia is the largest Muslim country in the world with the potential of zakat is also large, but it has not been supported by the reality of zakat collection. According to Kahf (1989) Firdaus et al (2012) Firmansyah (2013) and Canggih (2017). Known zakat collection each year has increased. In 2018 it is projected to increase by 58\%. But the figure is still 3.2\% of its potential (PUSKAS BAZNAS, 2017).

It is known that the largest zakat fund collection in West Java Province compared to other provinces is Rp. 68 billion with a ratio of effectiveness of zakat fund absorption (ACR) of $74.82 \%$, which means that it is categorized as effective. This indicates that there 
is still a gap between collection and distribution in zakat funds. Even though zakat funds should not be left over (An-Nabhani, 2010).

Zakat is an income distribution instrument that has been historically and normatively recognized that has a relationship with macroeconomic policies (Ghofur, 2016). This encourages the government of each region to pay attention to the role of zakat funds managed by BAZNAS in each region as an effort to alleviate poverty (Marginingsih \& Sasana, 2009). In line with the obligation to pay zakat, it will be easier if it is supported by the government as a collector and distributor (Yussof, 2011). Has expressly set forth in the Qur'an At-Tawbah letter: 103 as follows:

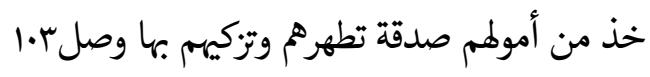

Meaning:"Take alms of their wealth, the charity you clean and purify them. Verily your prayer is the peace of their souls. And Allah hears again, knowing all."

The word "take it" in the word above is the command word to take zakat which is shown to some people, in this case the government as the party that is obliged to take care of the people (An-Nabhani, 2010). Based on the hadith from Ibn Umar Ra.: "Give your alms to those who are made by Allah as rulers of your affairs" (HR Baihaqi). This is reinforced by historical facts or shirah that the taking of zakat is carried out by the government. Like when the leadership was held by the Caliphs who always sent officers to take zakat (Ghofur, 2016).

As recommended by Dornbusch (2004) in Athoillah M.A. (2014) that shifting (distributing) income to underprivileged families will increase overall consumption and stimulate the economy. This statement is reinforced by the results of research by Suprayitno (2013), Azam (2014), Senadjki (2015) and Shaikh (2016) which states that zakat affects the level of poverty.

Based on the phenomenon of the problem and the results of previous studies. The author is interested in examining the influence of economic growth and the distribution of zakat funds to the level of poverty in The Third District of West Java Province.

\section{Literature Review}

The Most concepts of poverty are often associated with economic aspects. It deserves to be pinned in the context of a development country. That has a poverty problem and revolves around two main aspects, the level of poverty itself and large inequality in income distribution (economic disparity) (Athoillah M. A., 2014). 
Based on the measurement point of view, poverty is divided into two. Absolute and relative poverty (Subandi, 2012). Absolute poverty refers to a consistent standard. Someone including the absolute poor if the income is below the poverty line. it is meant had not enough in minimum living needs (Kuncoro, 2010).

Various attempts to alleviate poverty have been carried out by the government which are applied in the form of policies both directly and indirectly (World Bank, 2005). This is included in the development process, which had a positive or negative impact on the people of the country.

There are several aspects analyzed in relation to economic development issues. These are become the focus of economists' efforts to increase economic growth through increasing real income. The problems faced by development Country can be solved by what is known as trickle down effect (Pendi Dewanto, 2014). Economic growth rates can have a positive impact on poverty reduction if economic growth occurs in favor of the poor (Soleh, 2015).

In actual economic activities, economic growth means the fiscal development of the production of goods and services that publish by (BPS, 2018). However, to measure production units is very difficult, then what we can see is the income as a measure of achievement of an economic development (Sukirno, 2010).

In this study to determine economic growth in the form of a basic measure of economic performance at the regional level is using regional gross domestic product (GRDP) (Rahman, 2013). According to Bank Indonesia (2016) GRDP calculation uses two kinds of prices, namely GRDP at current prices and GRDP at constant prices. GDP at constant prices is used to see regional economic growth (Susanti, 2013).

In the other hand, the concept of Islamic economics that recognizes poverty and income distribution problem is a phenomenon that can not be separated (Huda dkk, 2015). The occurrence is a reasonable and sunnatullah ((Mubarokah, Beik, \& Irawan, 2017). It will not be called poor if nothing is rich. Because Allah created everything in pairs as explained in Qs. Yasin: 36:

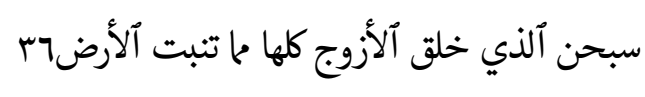

means: "The Most Holy (Allah) has created all pairs, both from what is grown by the earth and from themselves, as well as from what they do not know."

Therefore Islamic economists argue that these issues can be overcome by applying Islamic principles in basic operations such as the application of zakat instruments (Senadjki, 2015). Normatively, zakat is the most important social security system in 
Islam (Athoillah A. R., 2015). The theory said that zakat will reduce the level of poverty and reduce the income gap (Anriani, 2010).

The statement was reinforced by the research of Suprayitno, Kader, \& Harun (2013) who found that the distribution of zakat had a positive but small impact on aggregate consumption. In addition, empirical studies in Pakistan by Azam, Iqbal, \& Tayyab (2014) stated that zakat significantly improves household welfare and alleviates poverty. The results of his research show that there is an inverse relationship between poverty and zakat disbursement both in the short and long term.

Another study conducted by Senadjki (2015) shows that zakat does not have a significant effect on income inequality seen from this coefficient, but zakat significantly reduces both poverty incidence and hardcore poverty. Then Shaikh (2016) stated that the results of the study were that zakat institutions had sufficient potential to contribute to poverty alleviation. The potential for collecting zakat from aggregate resources in 17 OIC countries if it is collected together will be enough to alleviate poverty in all OIC countries combined.

The paradigm of economic development has been dependent on the concept of economic growth for a long times(Huda dkk, 2015). Through the process of increasing production of an economy which is realized in the form of an increase in national income (Soleh, 2015). This is possible because it sees the experience of successful economic development in developed countries which always refers to the operation of the market mechanism (An-Nabhani, 2010). In fact, as has been explained, the increase in per capita income also does not reflect real income in the community (Juliana, 2018).

Therefore, it is necessary to offer concepts that come from outside the system that have been used, and are able to be applied in real (Ghofur, 2016). Presumably distribution instruments in Islamic economics can be offered for the creation of welfare in the community. One of them is through the basic operation of the implementation of zakat instruments (Senadjki, 2015).

\section{Methodology}

This research uses descriptive-causality method. The type of sampling used is purposive sampling. The sample in this study is an indicator of the variables that examine the impact of economic growth projected with GRDP at constant prices and zakat distribution funds to the level of poverty in The Third District of West Java Province in the period 2011-2016. By using data collection techniques of library research from secondary data 
types from BPS publication sources and annual reports from BAZNAS institution in The Third District of West Java Province, so that it can be used directly by researchers.

The data in this study is a combination of time series data with cross section data. We can called as panel data, so that the analysis used is panel data regression (Rohmana, 2013). By using Eviews 9 as the application to analize it. But in order to fulfill the assumptions underlying the analysis of variance, the data was transformed first. The main goal is to change the scale of the original data measurement into another form. One of them is using the Log $X$ transformation. Logarithmic transformations are used if the data does not meet the assumption of additive influence. If $X$ is original data, then $X^{\prime}\left(X\right.$ accent) is the result of transformation data where $X^{\prime}=\log X$. So $X=X^{\prime}$ (Hidayat A., 2013). In the study of any data transformed were using transformed lognatural (Ln), so that the equation be changed:

$$
L n Y_{i t}=\beta_{0}+\beta_{1} \operatorname{Ln} X_{1 i t}+\beta_{2} \operatorname{Ln} X_{2 i t}+\varepsilon_{i t}
$$

Networks stages of data analysis using panel data regression begins with the selection of the best models that are used for estimating. There are pooling least square (Common effect), fixed effects approach (fixed effect), the approach of random effects (Random effect) (Widarjono, 2009). By using several testing three model estimation techniques (Ekananda, 2015) Then a series of classic assumptions testing related to data regression was carried out (Basuki, 2016)

After that hypothesis testing can be measured from the goodness of fit in the regression function. Statistically, this analysis can be measured by the statistical value $t$, the statistical value $F$, and the coefficient of determination (Widarjono, 2009). This regression analysis aims to determine partially and simultaneously the influence of independent variables on the dependent variable and to determine the proportion of independent variables in explaining the changes of dependent variable (Ekananda, 2015).

\section{Result}

\subsection{Test results of hypothesis}

\subsubsection{Partial test (t test)}

One of the hypothesis testing by $t$ test. $T$ table values in this study were obtained from the tables of $t$ and $\alpha$ and distribution degree of freedom (df), where $\mathrm{df}=\mathrm{nk}=24-3$ $=21$, then with df 21 and $\alpha=5 \%(0.05) \mathrm{t}$ table is 1,721. Furthermore, the calculated $\mathrm{t}$ 
value will be compared with the value of $\mathrm{t}$ table to determine the decision to accept $\mathrm{H}_{0}$ or reject $\mathrm{H}_{0}$. As well as the probability will be compared with the error rate or alpha determined by the researcher (Rohmana, 2013). Based on the results of testing using program Eviews 9, the t test will presented in the following discussion:

TABLE 1: T Test Results Research Data.

\begin{tabular}{l|c|c|c|c|}
\hline Variable & Coefficient & Value t-count & Value of t-table & Prob Value. $\mathbf{t}$ \\
\hline $\mathbf{X 1}$ & -0.325349 & -2.999205 & 1.721 & 0.0077 \\
\hline $\mathbf{X 2}$ & -0.001631 & -0.088463 & 1.721 & 0.9305 \\
\hline
\end{tabular}

Based on the regression $t$ test for economic growth variables in Table 1 indicate that the $t$-count value is (-2999) for the analysis of the $t( \pm)$ considered absolute, then $t$ count is (2.999) and the number is greater than $t$ table (1.721) which means rejecting $\mathrm{H}_{0}$ or receiving $H_{1}$. Then the probability level is 0.0077 which means it is smaller than $\alpha=$ (0.05). So it can be concluded that economic growth is significant to the level of poverty in a negative direction. This shows that every increase in economic growth by $1 \%$, it will affect the decline in the number of poor people by $0.325 \%$.

As for the regression of $t$ test for variables and distribution of zakat in Table 1, it is known that the value of $t$ count $(0.088)$ is smaller than $t$ table (1.721) which means receiving $\mathrm{H}_{0}$ or rejecting $\mathrm{H}_{1}$. Then the probability level of 0.93 is greater than $\alpha=(0.05)$. So it can be concluded that the distribution of zakat is not significant to poverty in a negative direction. This shows that every increase in zakat distribution funds by $1 \%$ has not affected the decline in the number of poor people by $0.001631 \%$.

\subsubsection{Simultaneous test (Test F)}

Based on the results of the panel data regression test. $\mathrm{F}$ value calculated (F-statistic) was 2297,985 and probability value $F$ (Prob. F) was 0.000000 . Thus the calculated $F$ value $>\mathrm{F}$ table value and the probability value $\mathrm{F}$ <significance level is 0.05 . So the results of the $\mathrm{F}$ Test concluded that the two independent variables namely economic growth and the distribution of zakat funds simultaneously affect the dependent variable, namely poverty. 


\subsubsection{Determination coefficient (R2)}

Panel data regression analysis with model fixed effect shows the R2 value is 0.998436 and the adjusted R2 (Adjusted R-squared) value is 0.998001 . This means that 99.8 percent of poverty can be explained by both independent variables (economic growth projected with GDP per capita and zakat distribution funds. As for 0.2 percent is influenced by other factors not included in the regression model. R2 value in regression model is the coefficient of determination is very high because it is above 50 percent.

\subsection{Discussion}

\subsubsection{Effect of economic growth to Poverty}

Developments of economic growth projected with the GDP Constant Market Prices in The Third District of West Java has increased annually (BPS, 2017). This means there is an increase real regional income in the Region / City in The Third District of of West Java Province from various sectors of production of goods and services.

The results of this study are in line with the hypothesis, where economic growth can influence the level of poverty. This is in accordance with economic theory based on the theory trickle-down effect which was first developed by Arthur Lewis (1954) (Subandi, 2012). The theory implies that economic growth will be followed by a vertical flow from the rich population to the poor that will happen automatically (Kuncoro, 2010). The benefits will be felt by the rich first, then at a later stage the poor begin to benefit when the rich population starts to spend the results of the economic growth they have received (Todaro, 2006). Thus, the influence of economic growth on reducing poverty is an indirect effect by the vertical flow of the rich population to the poor (Soleh, 2015).

This is in accordance with the inverse $U$ theory proposed by Kuznet, said in the long run there will be a negative relationship between economic growth and poverty level (Hartini, 2017) This means that an increase in economic growth will reduce poverty (Todaro, 2006). That way, if high GRDP growth means there will be more better jobs and a higher level of income, as well as a larger tax base that allows the government to do more for the poor, this is according to Norton (2002) in Wirawan and Arka (2015). Therefore this relationship shows the importance of accelerating economic growth to reduce poverty.

The one of pervious research that is in line with this research is that conducted by Azami (2009), Momongan (2013) and Arka (2015). In the other hand not in line with this 
research is Pendi Dewanto (2014) which is supported by the concept of growth with equity. In the strategy growth with equity, priority is economic growth and not equity. In contrast to the concept of balance as a strategy of growth and equity. It is said that the strategy implemented by the Indonesian government is a strategy of growth with equity and not a strategy of growth and equity. (Yanah, 2014). That is similar with the concept of economic growth in Islam which not only requires balanced economic growth, but even maintains and maintains a balanced distribution of wealth. So that a safety valve is needed in distribution (Hidayat A., 2015)

\subsubsection{The effect of Zakat distribution funds on poverty}

The Collection of zakat in Indonesia and especially in The Third District of West Java Province has increased every year. This also happens in its distribution. But the contribution to poverty is still very small in aggregate. This is because the funds for the distribution of zakat are still far from the actual potential of zakat collection (Firmansyah, 2013). This phenomenon occurs evenly in regional authorities in Indonesia, especialy in The Third District of West Java Province.

The results of this study do not align or reject the hypothesis that has been described before. But it does not mean rejecting the concept of zakat according to Pramanik (1993) in Beik (2009) that zakat has a very significant role in redistributing income and wealth in Muslim societies. However, there are two reasons why the proposed hypothesis is not supported statistically. First, the collected data did not succeed in proving the hypothesis. Second, there was an error from the researcher. In the case of the first error, sometimes a large sample is needed to prove the relationship of two variables, especially if the relationship is small as the sample in this study. Therefore, a research review that is in line and not in line with the results of this study is needed in order to explain that the results of this study are relevant to other studies.

This research is supported by research conducted by Kahf (1989), Firdaus et al (2012) and Canggih (2017) which shows the facts on the ground about the potential and optimization of the role of zakat in Indonesia has not been fully exploited optimally because the role of zakat has not been implemented effectively and efficiently (Amalia, 2012).

The funds for the distribution of zakat to the three BAZNAS in Region III of West Java Province were analyzed descriptively. Found zakat distribution per program area which has the most portion is da'wah which is a non-economic activity. While the distribution in the economic sector alone only has a portion of $1 \%-42 \%$ of the distribution of the 
program. While in the distribution of total zakat funds, the portion is $1 \%-17 \%$. This is seen from the summary of zakat reports on each BAZNAS in The Third Distric of West Java Province. So it can be concluded that the majority of zakat funds are intended for non-economic activities but can indirectly increase the economy even though its role has not been felt in aggregate. This is because the scale is still very small. But the slightest goodness promised by God will get a reply. In accordance with Al Quran surah An-Nisa verse 40 . While any kind of alms will grow and give blessings to the property. As Allah said in Al-Quran Surah Al Baqarah verse 261.

Whereas the highest distribution per asnaf in the three BAZNAS analyzed is faqirmiskin who have a distribution portion of $43 \%-86 \%$ of distribution per asnaf and distribution of total zakat funds is $43 \%-77 \%$. Where according to Imam Al Ghazali is a group of people whose minimum needs have not been fullfiled yet (Huda dkk, 2015). Then it can be concluded that the majority of zakat distribution funds are for consumption.

The lowest distribution of zakat per program area is different for each BAZNAS because the programs planned and conditions in each region vary. But the distribution to Asnaf gharimin and the riqab lowest on the three BAZNAS that has described. This is because status Gharimin's is personal privacy and difficult to identify, while the riqab is estimated to be no longer in the current social status of the community.

Based on descriptive analysis which is seen from the figure of the distribution of zakat funds. It is known that there is still a lot of zakat potential in The Third District of West Java Province which has not been compiled. This is because the distribution rate is still small for the size of a regional authority. Based on Firdaus \& al's statement. (2012) that zakat collection in Indonesia is still $1 \%$ of its potential. The ACR in West Java is still categorized as Effective, meaning that the distribution of zakat is still around 75\% of the total collection (PUSKAS BAZNAS, 2017). And remembering in this study the object of research studied was only BAZNAS agencies whose scope did not reflect the distribution of zakat funds in aggregate, especially those discussed in this study, namely in Region III of West Java Province. This is because there are many other Zakat Institutions in The Third District of West Java Province whose population is not known with certainty and their role is not examined in this study regarding the distribution of zakat funds to poverty.

The role of zakat as a solution to poverty alleviation in aggregate is still underestimated because of its small scope. Whereas Indonesia, which has a majority of its Muslim population, has a huge amount of zakat potential (Firmansyah, 2013). Therefore in implementing the zakat fund management commitment and government support is 
needed as a very important variable in supporting the success of zakat development (Yussof, 2011). Especially in those discussed about The Third Distict of West Java Province. For example, a country that has successfully implemented zakat policy is Malaysia (Firmansyah, 2013). As with the results of research from international journals written by Suprayitno, Kader, \& Harun (2013) who found that the distribution of zakat has a positive impact on aggregate consumption, but the impact is small and short-term. Senadjki (2015) in his research shows that zakat does not have a significant influence on income inequality seen from this coefficient, but zakat significantly reduces both poverty incidence and hardcore poverty. Beik's research (2009) empirically proves that zakat can reduce the number of poor families, income inequality and the severity of poverty in poor families. This shows that zakat has great potential as an instrument to reduce poverty and unemployment (Beik I. S., 2010).

In general, all the literature on zakat stated that zakat is an instrument that is in accordance with sharia in an effort to reduce poverty and improve social welfare for Muslim communities. As poverty reduction programs compulsory (mandatory expenditure) in the Islamic economy. The impact is significant and zakat is supposed to run automatically (built-in) in the Islamic system (Darna \& Fatimah, 2016).

\section{Conclusion}

Both independent development variables, namely economic growth projected with GRDP at constant prices and the amount of zakat distribution have different interpretations in explaining the effect on the poverty as dependent variable projected by the number of poor people. There is a negative influence between economic growth and poverty. This indicates that increased real regional income is absorbed for poverty reduction efforts. While the distribution of zakat funds is said to have no significant effect on the negative direction of poverty. This means that the distribution of zakat funds does not affect the level of poverty. In addition, recommendations that can be given as follows: Determination of poverty line according to maqashid sharia. Implementation of the growth and equity strategy that is using the rate of economic growth is expected to illustrate the reality of the actual spread. Stay optimistic about the role of zakat as an instrument of income distribution and the synergy of various parties in improving the quality of zakat management, especially in The Third District of West Java Province and generally in all regions in Indonesia. The addition of the sample size from the research 
object and the sample characteristics of the Zakat variable must be expanded, so that not only BAZNAS institution.

[1] Almizan. (2016). Distribusi Pendapatan: Kesejahteraan Menurut Konsep Ekonomi Islam. Maqdis (Jurnal Kajian Ekonomi Is/am)-Volume 1, No.1,.

[2] Amalia, KM (2012). Potensi dan Peranan Zakat dalam Megentaskan Kemiskinan di Kota Medan. Jurnal Ekonomi dan Keuangan, Vol. 1, No.1, Desember 2012.

[3] An-Nabhani, T. (2010). Sistem Ekonomi Islam. Bogor: Al Azhar Press.

[4] Anriani. (2010). BAZ Kota Bogor dan Pengentasan Kemiskinan. Iqtishodia Jurnal Ekonomi Islam Republika.

[5] Athoillah, AR (2015). Distribusi Zakat di Indonesia: Antara Sentralisasi dan Desentralisasi. Ijtihad, Jurnal Wacana Hukum Islam dan Kemanusiaan, Vol. 15, No. 2 .

[6] Athoillah, MA (2014). Zakat untuk Kesejahteraan Bangsa. Media Syariah, Vol. XVI No. 1.

[7] Azam, M., Iqbal, N., \& Tayyab, M. (2014). Zakat and Economic Development: Micro and Macro Level Evidence from Pakistan. Bulletin of Business and Economics, 3(2), pp. 85-95.

[8] Azami, PA (2009). Analisis Pengaruh Pertumbuhan Ekonomi, Tenaga Kerja dan Pendidikan terhadap Kemiskinan: Studi Kasus Provinsi Jawa Timur Tahun 20012007. Jurnal Riset Ekonomi Universitas Airlangga Surabaya.

[9] Bank Indonesia. (2016). Produk Domestik Regional Bruto (PDRB). Metadata Informasi Dasar Departemen Statistik Ekonomi dan Moneter.

[10] Basuki, AT (2016). Analisis Regresi Dalam Penelitian Ekonomi. Depok: PT Rajagrafindo Persada.

[11] Beik, IS (2009). Analisis Peran Zakat dalam Mengurangi Kemiskinan: Studi Kasus Dompet Dhuafa Republika. Zakat \& Empowering Jurnal Pemikiran dan Gagasan Vol II 2009.

[12] Beik, IS (2010). Pera Zakat Mengentaskan Kemiskinan dan Kesenjangan. Iqtishodia Jurnal Ekonomi Islam Republika.

[13] BKPP JABAR. (2018, Mei 9). Badan Koordinasi Pemerintahan dan Pembangunan Wilayah III. Dipetik Mei 9, 2018, dari http://www.jabarprov.go.id:http://bakorembangwilcrb.jabarprov.go.id

[14] BPS. (2017). Produk Domestik Regional Bruto Kabupaten/Kota di Indonesia 20122016. Jakarta: Badan Pusat Statistik (BPS). 
[15] BPS. (2018). Berita Resmi Statistik Profil Kemiskinan di Indonesia Maret 2018 No. 57/07/Th. XXI, 16 Juli 2018. Jakarta: BPS.

[16] BPS. (2018). Berita Resmi Statistik Tingkat Kemiskinan dan Ketimpangan di Jawa Barat Maret 2018 No.38/07/32/Th. XX, 16 Juli 2018. Bandung: BPS.

[17] BPS. (2018). Statistik Indonesia 2017. Jakarta: BPS SSN: 0126-2912.

[18] Canggih, CF (2017). Potensi dan Realisas Dana Zakat di Indonesia. al-Uqud: Journal of Islamic Economics, 20.

[19] Darna, \& Fatimah. (2016). Peran Organisasi Pengelola Zakat Nasional Dalam Memutus Rantai Kemiskinan di Indonesia. National Conference of Applied Sciences, Engineering, Business and Information Technology. Politeknik Negeri Padang, 15 16 Oktober 2016 ISSN:2541-111X.

[20] dijawabarat.com. (2018, April 3). Kabupaten/Kota Termiskin di Jawa Barat. Dipetik Agustus 6, 2018, dari https://dijawabarat.com/:https://dijawabarat.com/kabupatentermiskin-di-jawa-barat-terbaru/

[21] Dornbusch, F. d. (2004). Shifting income to less wealthy families will increase overall consumption and stimulate the economy.

[22] Ekananda, M. (2015). Ekonometrika Dasar Untuk Penelitian Ekonomi, Sosial dan Bisnis. Jakarta: Mitra Wacana Media.

[23] Firdaus, \& al., e. (2012). Economic Estimation and Determinations of Zakat Potential in Indonesia. IRTI Working Paper Series.

[24] Firmansyah. (2013). Zakat Sebagai Instrumen Pengentasan Kemiskinan dan Kesenjangan Pendapatan. Jurnal Ekonomi dan Pembangunan Vol 21, No. 2, Desember 2013.

[25] Ghofur, RA (2016). Peran Instrumen Distribusi Ekonomomi Islam Dalam Menciptakan Kesejahteraan di Masyarakat. IKONOMIKA Jurnal Ekonomi dan Bisnis Islam (Journal of Economics and Business Economics Islam) Volume 1, Nomor 1.

[26] Hartini, NT (2017). Pengaruh PDRB Per Kapita, Investasil dan IPM Terhadap Ketimpangan Pendapatan Antar Daerah dl Provinsi DIY Tahun 2011-2015. Jurnal Pendidikan dan Ekonomi, Volume 6, Nomor 6.

[27] Hidayat, A. (2013, 01). Transformasi Data. Dipetik 09 03, 2018, dari statistikian.com: https://www.statistikian.com/2013/01/transformasi data.html

[28] Hidayat, A. (2015). Manajemen Zakat Dan Prilaku Konsumsi Mustahik. Banking and Management Review Vol 4 No 22015 ISSN 2252- 8520.

[29] Huda dkk, N. (2015). Ekonomi Pembangunan Islam. Jakarta: Prenadaedia Group.

[30] Indonesia-Investments. (2018, 02 11). https://www.indonesia-investments.com/id/ keuangan/angka-ekonomi-makro/kemiskinan/item301? Diambil kembali dari https: 
//www.indonesia-investments.com/id/: https://www.indonesia-investments.com/id/ keuangan/angka-ekonomi-makro/kemiskinan/item301?

[31] Juliana, RM (2018). Pertumbuhan dan Pemerataan Ekonomi Perspektif Politik Ekonomi Islam. AMWALUNA Jurnal Ekonomi dan Keuangan Syari'ah Vol 2, No 2,.

[32] Kahf, M. (1989). Zakat: Unresolved Issues in the Contemporary Fiqh. Journal of Islamic Economics, 2 (1), pp. 1-22.

[33] Kuncoro, M. (2010). Dasar-dasar Ekonomi Pembangunan. Yogyakarta: UPP STIM YKPN.

[34] Marginingsih, R., \& Sasana, H. (2009). Pengaruh Pendayagunaan Dana ZIS dan PDRB Per Kapita Terhadap Jumlah Penduduk Miskin (Studi Kasus di Kabupaten/Kota Provinsi Jawa Tengah Tahun 2006-2009). UNIVERSITAS DIPONEGORO.

[35] Momongan, JE (2013). Investasi PMA dan PMDN Pengaruhnya Terhadap Perkembangan PDRB dan Peyerapan Tenaga Kerja Serta Penanggulangan Kemiskinan di Sulawesi Utara. Jurnal EMBA Vol.1 No.3 September 2013, Hal. 530-539 ISSN 23031174.

[36] Mubarokah, I., Beik, IS, \& Irawan, T. (2017). Dampak Zakat terhadap Kemiskinan dan Kesejahteraan Mustahik (Kasus: BAZNAS Provinsi Jawa Tengah). Jurnal A/Muzara'ah Vol.5, No.1,.

[37] Pendi Dewanto, R. d. (2014). Analisis Pengaruh Pertumbbuhan Ekonomi dan Ketimpangan Penndapatan Terhadap Pengentasan Kemiskinan di Kawasan Mebidangro. Jurnal Ekonom, Vol 17, No 3,.

[38] Pramanik, AH (1993). Development and Distribution in Islam. Petaling Jaya: Pelanduk Publications.

[39] PUSKAS BAZNAS. (2017). Outlook Zakat Indonesia 2018. Jakarta: Pusat Kajian Strategis Badan Amil Zakat Nasional (BAZNAS).

[40] Qaradhawi, Y. (2005). Spektrum Zakat. Jakarta: Zikrul Hakim.

[41] Rahman, MS (2013). Relationship among GDP, Per Capita GDP, Literacy Rate and Unemployment Rate. British Journal of Arts and Social Sciences ISSN: 2046-9578, Vol.14 Noll.

[42] Rohmana, Y. (2013). Ekonometrika Teori dan Aplikasi dengan Eviews. Bandung: Laboratorium Penndidikan Ekonomi dan Koperasi UPI.

[43] Senadjki, A. (2015). The Impact of Zakat on Income Inequality and Poverty in Malaysia: A Panel Data Analysis. Market Forces College of Management Sciences. [44] Seth, N. (2002). Economic Growth and Poverty: In Search of Trickle Down. Cato Journal, 22(2): pp: 263-275. 
[45] Shaikh, SA (2016). Zakat Collectible in OIC Countries for Poverty Alleviation: A Primer on Empirical Estimation. International Journal of Zakat 1 (1) 2016 page 17-35. [46] Soleh, A. (2015). Pertumbuhan Ekonomi dan Kemiskinan di Indonesia. Ekombis Review.

[47] Subandi. (2012). Ekonomi Pembangunan. Bandung: ALFABETA.

[48] Sukirno, S. (2010). Makroekonomi Teori Pengantar. Jakarta: PT RajaGrafinndo.

[49] Suprayitno, E., Kader, R., \& Harun, A. (2013). The Impact Of Zakat on Aggregate Consumption in Malaysia. Journal of Is/amic Economics, Banking and Finance, 9(1), pp. 39-62.

[50] Susanti, S. (2013). Pengaruh Produk Domestik Regional Bruto, Pengangguran dan Indeks Pembangunan Manusiaterhadap Kemiskinan di Jawa Barat dengan Menggunakan Analisis Data Panel. Jurnal Matematika IntegratifVol. 9 No. 1,.

[51] Syahrul, U. (2009). Pengaruh Anggaran Pengeluaran Pemerintah, Dana ZIS dan PDRB per Kapita Terhadap Kemiskinan (Studi Kasus DKI Jakarta). Jakarta: Tesis Universitas Indonesia.

[52] Todaro, M. (2006). Pembangunan Ekonomi. Jakarta: Erlangga.

[53] Widarjono, A. (2009). Ekonometrika Pengantar dan Aplikasinya.Edisi Ketiga. Yogyakarta: Ekonesia.

[54] Wirawan, IM, \& Arka, S. (2015). Analisis Pengaruh Pendidikan, PDRB per Kapita dan Tingkat Pengangguran Terhadap Jumlah Penduduk Miskin Povinsi Bali. E-Jurnal EP Unud, 4 [5]:546-560 ISSN: 2303-0178.

[55] World Bank. (2005). Mengurangi Kemiskinan. Indonesia Policy Briefs - Ide-ide Program 100 Hari.

[56] Yanah. (2014). Strategi Pengentasan Kemiskinan Di Indonesia Melalui Sinergi Antara Bank Syariah dan BAZNAS. Jurnal Ekonomi ISSN: 2302-7169 Vol. 2 No. 3 Mei-Agustu 2014.

[57] Yussof, MB (2011). Zakat Expenditure, School Enrollment, and Economic Growth in Malaysia. International Journal of Business and Social Science, 2 (6). 175-181. 